\title{
1. The Belt and Road Initiative and global governance: by way of introduction
}

\section{Maria Adele Carrai, Jean-Christophe Defraigne and Jan Wouters}

President Xi Jinping's launch of the Belt and Road Initiative (BRI) in 2013 engendered a prolific global debate about its nature, its effects on global governance and institutions, and the types of development model it is projecting abroad (Wang, Y. 2016; Zhao 2010; Zhou and Esteban 2018; Naughton 2010; Cai 2017; Callahan 2016). Some scholars have not given much credit to the BRI, believing it similar to empty mottos used in Chinese foreign policy in the past - such as peaceful development, harmonious society or community of shared destiny - and that it will soon vanish from the debate. The initiative has proven itself to be of a long-term nature, however; rather than disappearing any time soon, it will have enduring effects on the international order and society. Indeed, it has been seen as one of the largest international ordering projects since the Marshall Plan. Much has been written about the BRI already, and due to its nature, magnitude and support from the Chinese central government we can expect much more scholarship in the future.

While many developing countries have seen the initiative as a great opportunity to attract much-needed investments in infrastructure, other countries see it as a way for China to solidify its global reach by creating a network of dependencies. In reflecting the aspirations of China as an emergent global power, the BRI has been perceived by many as a threat specifically because China might challenge the rules-based international order, reciprocity, non-discrimination and openness of international markets. The initiative's most vocal critic has been the United States (US), but recently the European Union (EU) has also become more outspoken about China and the BRI. It is significant, for example, that the European Commission and the EU's High Representative for Foreign Affairs and Security Policy recently described China as a "systemic rival promoting alternative models of governance" (ECHR 2019). Other developing 
countries have also perceived the BRI with suspicion, but in many cases China has become one of the very few options for funding important infrastructure projects.

The allegation that China is promoting alternative governance models comes not only at a time of crisis for global governance and the multilateral rules-based order, but also at a time when China, an authoritarian country with a hybrid form of capitalism and socialism, is increasingly asserting itself. No less than any other power, China is likely trying to shape the international order and global governance in a way that better supports and fits its own interests. Even if it is not acting with specific intent to modify global governance structures, China's sheer dimensions mean that its abstention from or support for aspects and institutions of global governance may have a huge impact on the system, and long-term repercussions within it. If the BRI, and China's increased economic and political power more generally, can contribute to shaping global governance, how can such effects be measured? While the concerns about the initiative are broad and real, it is difficult to pin down exactly what it means for China or the BRI to be promoting alternative models of governance. Much of the vast literature that directly or indirectly addresses the BRI and (global) governance lacks a balanced approach and often does not look at specific data or facts. This volume brings together the two themes in an attempt to provide more balanced and concrete answers to the question of how China is impacting global governance. Based on a conviction that global governance cannot be understood solely at an abstract level, but must also be looked at from specific and "from-the-ground" angles of incidence, the book presents qualitative case studies from the BRI in relation to the topic.

But what exactly is the BRI? At first glance, it is a developmental strategy promoted by the People's Republic of China (PRC) to foster mercantile connectivity and cooperation among countries. It brings together Eurasian and Northern African economies through the creation of a network of infrastructures, some of which were already in place, that runs over land (the Silk Road Economic Belt, known as "the belt") and sea (the 21 st Century Maritime Road, known as "the road"). ${ }^{1}$ It is a very ambitious programme that is perceived as being able to transform and redefine the twenty-first-century global economy and governance. The project could indeed have huge geopolitical implications, as it could eventually span over 75 countries, 60 per cent of the world's population and a large portion of the world economy (Chin and He 2016, pp. 2-3). Besides contributing to increased regional cooperation, economic integration, industrial upgrading, connectivity and economic development, the BRI is generally believed to be an important outlet for Chinese products, services and overseas investments, allowing for the development of China's western regions, the 
diversification of its sizable foreign exchange reserves and capital and, as will be discussed, the internationalization of the renminbi (RMB). ${ }^{2}$

President Xi Jinping openly promoted the BRI for the first time in a September 2013 speech at Kazakhstan's Nazarbayev University (Xi 2013). In light of centuries of interaction and cooperation between the countries along the ancient Silk Road, and given the golden opportunity for developing China's relations with Central Asia, Xi called for an innovative approach to foster a joint effort to build "an economic Belt along the Silk Road" (Miner 2016, p. 13). The initiative's official status was furthered in 2015 when the National Development and Reform Commission, the Ministry of Foreign Affairs and the Ministry of Commerce of the PRC issued a joint statement on it, with the authorization of the State Council (NDRC 2015). In March 2016, the implementation of the BRI was included in China's 13th Five-Year Plan for National Economic and Social Development, an economic initiative that guides the economic policies of the country for a five-year period. In May 2017, the principles contained in the joint statement were reaffirmed in the Belt and Road Forum held in Beijing, which attracted world leaders and top officials from more than 130 countries. ${ }^{3}$ Although the main source of BRI financing continues to be China policy banks, new international development financing institutions, such as the Asian Infrastructure and Investment Bank (AIIB) and the Silk Road Fund, were created in relation to the implementation of the BRI. As the New Development Bank's president, K.V. Kamath, remarked, "One Belt One Road is not one project. It is a series of projects in various areas, running across Asia in various tracks" (Roychoudhury 2017). In this sense the BRI is a slogan Xi has used to describe various investments, many of which were already in place, thus giving the sense of a more coherent foreign policy, or a "grand strategy," worthy of China's new status as a global power. It is for this reason that the BRI does not yet have a formalized institutional structure: it is managed in a flexible way, without a rigid legal structure. Many see it as incoherent. In this sense it does appear to resemble a motto, or even an imaginary, that is constantly reinterpreted by whichever stakeholder appropriates it. Yet no matter how imagined it is, the BRI's repercussions on different economies and their development are real. It is already possible to see how existing projects have been re-labelled and inserted into the initiative, how funds have been redirected to sectors often forgotten, and how new centres and institutions have been created specifically to deal with it.

The BRI must also be understood as a global geopolitical and economic strategy, however. From a strategic point of view, China's leadership is trying to avoid being contained by the US and its allies. The fact that China's geographical position is not as advantageous as that of the US can 
fuel fears of encirclement among the Chinese leadership. China has very long land borders with 14 sovereign states (only Russia matches it in this regard, while the US has land borders with only two countries). China is facing powerful neighbours - India and Japan but also Russia - who are worried by its sudden transformation into a regional and global power. Many US strategists consider China to be the only power capable of challenging America's geopolitical hegemony, and argue for a containment policy against its expansion (Pillsbury 2015; Navarro 2015; Woodward 2017). These responses suggest that China's geopolitical and commercial expansion will face more serious resistance than that of any other rising power. In terms of access to the sea, the US's exclusive economic zone (EEZ) is second largest in the world, just behind that of France (both are more than 11 million kilometres square), while China's non-contested EEZ only ranks 33rd. Even if China could convince its neighbours, other powers and the United Nations (UN) to accept what it considers as its legitimate EEZ, this would still be almost three times smaller than that of the US or France, and smaller than Japan's. China has direct access to only one sea and is surrounded by numerous military bases belonging to the US or US allies (such as Japan, South Korea and Taiwan). A large part of its energy needs and trade passes through the Strait of Malacca, an area the US can quickly dominate in terms of navy and air capacity. During the Maoist period, this situation was not so problematic for China as it relied mostly on the Soviet bloc in the 1950s and became almost autarchic in the 1960s and 1970s. However, the economic reforms that opened the Chinese economy after 1980 have generated a greater need for raw materials from the rest of the world, forcing China's leadership to think about how to secure its access to strategic commodities (Shambaugh 2013). Deng Xiaoping's adage about biding time no longer fits the needs of the economic giant that the country has become. As China's weight in the world economy soared in the 2000s, it generated anxieties among the political and economic elites of China's neighbours and Western powers. While the Clinton administration had labelled China as "strategic partner," the Bush administration switched to "strategic competitor" (Baum 2001).

The 2008 financial crisis accelerated this trend. Although it slowed after 2012, the Chinese economy grew two to four times faster throughout the 2010s than those of the older economic powers, which had been more impacted by the financial crisis, the subsequent credit crunch and the deleveraging process. To counter this trend, Barack Obama's administration tried to find solutions to preserve US global economic and geopolitical leadership. The sheer economic weight of China has been generating a shift in the balance of power within the global economy and particularly in the Asia-Pacific, where China is, or will soon be, most countries' main 
trading partner. As most economic forecasts predict that the biggest rise in purchasing power over the next 30 years will be located in the Asia-Pacific, which will host more than 50 per cent of the global middle class by around 2050, it is quite logical that the US leadership wants to secure its economic and strategic presence in the region. In 2010, President Obama announced the "pivot to Asia," which implied a redeployment of economic diplomacy and strategic resources to the Asia-Pacific. Then US Secretary of State Hillary Clinton stated the objectives clearly:

Open markets in Asia provide the United States with unprecedented opportunities for investment, trade, and access to cutting-edge technology. Our economic recovery at home will depend on exports and the ability of American firms to tap into the vast and growing consumer base of Asia. Strategically, maintaining peace and security across the Asia-Pacific is increasingly crucial to global progress, whether through defending freedom of navigation in the South China Sea, countering the nuclear proliferation efforts of North Korea, or ensuring transparency in the military activities of the region's key players. (Clinton 2011)

The 2010s were characterized by a hardening of maritime territorial issues and military build-up between China and its neighbours. One can always blame such tensions on specific policies enacted by China or other powers, but the reality is simply that China's economic and technological rise has challenged nolens volens the former status quo, in which the US has been the uncontested dominant geopolitical power controlling the trade routes of the Asia-Pacific since the end of the Cold War.

The US has also become increasingly frustrated by the erosion of its influence in global economic governance. While it set most of the agenda of the General Agreement on Tariffs and Trade's Uruguay round (1986-1994), it failed to impose its objectives on the Doha round starting in 2001, known as the Doha Development Agenda (DDA). The rise of emerging economies - and notably of Brazil, Russia, India, China and South Africa (the BRICS) - has transformed the bargaining positions in the world trading system. This is one of the root causes of the deadlock in World Trade Organization (WTO) negotiations that aimed to liberalize further trade and investments. The "Washington Consensus" epitomized by the International Monetary Fund (IMF) and the World Bank was increasingly challenged in the 2000s, especially after the 2008 financial crisis highlighted the risks incurred by the financial deregulation supported by US economic and political leaders since the 1980s (Defraigne and Nouveau 2017). The frustration of the US became clearly visible after the stalemate of the 2003 WTO Ministerial Conference in Cancún. Then US Trade Representative Robert Zoellick blamed the failure on the G22, which is composed of developing countries (Bhagwati 2004). The US 
advocated "competitive liberalization,"4 that is, bypassing the opposition of large emerging economies by promoting deep WTO+ bilateral free trade agreements that often include provisions on trade-related aspects of international property rights (TRIPs) and investment measures (TRIMs), trade facilitation and procurements (Horn et al. 2009). While these moves were quickly copied by the EU, ${ }^{5}$ Japan and South Korea, they did not prevent China from gaining more influence in the global trading system, and the large emerging economies from blocking US and EU agendas on trade liberalization (Wouters et al. 2012).

Having in mind the impact of the 2008 crisis, the limits of the bilateral trade agreements strategy and the enduring stalemate over the DDA, the Obama administration tried to put forward gigantic schemes that could foster trade liberalization and marginalize the large emerging economies opposed to the US trade agenda - notably the BRICs. In the autumn of 2012, the Obama administration invited the EU to start negotiations for a Transatlantic Trade and Investment Partnership (TTIP). The goal was not merely mutual trade liberalization, as both economies are already very open. The idea was to impose common transatlantic standards in trade and investment that could become global standards, and strengthen the two partners' bargaining position vis-à-vis the large emerging economies, specifically China. This was openly admitted by the top negotiators. Karel De Gucht, EU Trade Commissioner, declared:

Perhaps the biggest value of an agreement will be in our relations with the rest of the world. Why? Because the EU and the US are the world's largest markets and the most influential regulators. Any common approach will double that influence. And it may shape regulation around the world, including in countries like Brazil, India, China and Russia, where today standards are typically much lower than in the US and the EU. (De Gucht 2014)

In early 2013, the Obama administration pressured Japan to join the ongoing negotiations to build a Trans-Pacific Partnership (TPP) without China or Russia. The TTIP and TPP include 60 per cent of the world economy in terms of GDP (according to 2013 figures), but keep the BRICS out. As the US, the EU and Japan have successfully negotiated many bilateral FTAs in Latin America, Africa and Asia, Chinese exports could be hurt by a lack of preferential market access.

As early as 2010, Wang Jisi, an influential professor of international relations at Peking University, outlined the idea that China should "march toward the West" to manoeuvre around Obama's pivot to Asia, and that it should rebuild the silk roads that once linked China to Asia (Griffiths 2017). Although some sources claim that Xi had already coined the BRI concept before he replaced Hu Jintao in autumn 2012 (Rolland 2017b), 
his first public presentation of it, in Astana and Jakarta in late 2013, came only a few months after the launch of TPP and TTIP negotiations. In that light, the BRI could be interpreted as a defensive response to avoid China's marginalization in the world trading system and to counter the US pivot to Asia. By deepening the economic integration of the Eurasian continent and creating numerous transportation corridors to Southeast Asia, South Asia, Central Asia, Europe, the Middle East and Africa, China's leadership is trying to avoid being displaced to the periphery of a US-centred world economy, as aimed for by US strategy. It could help China switch places by itself isolating the US from the Eurasian continent as the new global economic centre.

In developing the BRI, China's leadership has not been able to rely on the same tools that the US has at its disposal. China is still an emerging economy in many respects, and the Chinese government pursues an active industrial policy to continue to protect its infant national champions from international competition and enable their transformation into globally competitive enterprises. It therefore wishes to retain control over essential tools of industrial policy, such as: privileged access to procurement; indirect subsidies through cheap credit access provided by state-owned banks; specific technical barriers to trade; negative lists for foreign direct investment (FDI); and discretionary powers on the level of intellectual property rights enforcement in some strategic sectors where Chinese firms have to catch up with more technologically advanced competitors. This means that China cannot compete with the US, the EU or Japan by offering WTO+ latest-generation trade agreements to its trading partners. ${ }^{6}$ Instead of playing the card of a de jure economic integration with its BRI partners, as the US proposes with the TPP, the TTIP and other bilateral agreements, the Chinese government prefers to develop a de facto economic integration of the Eurasian continent and its neighbourhood that enables retaining national sovereignty on key industrial policy tools. The BRI is based on the development of infrastructure projects supported by mostly commercial loans and aid that should improve connectivity across the regions targeted, fostering trade and economic interdependence. With the BRI, China's leadership hopes to strengthen the country's soft power and economic clout vis-à-vis the US, without directly confronting what is still the global superpower.

The BRI and China's geopolitical and economic strategy is also related to global governance. While there are many different ways in which the terms "global" and "governance" are understood, "global governance" is here referred to as "the entirety of formal and informal processes between States, organizations (including intergovernmental and non-governmental organizations as well as business enterprises) and/or people, which aim 
to address global challenges through the formulation and enforcement of rules and standards, by giving incentives and guidance, generating information and knowledge and/or settling disputes" (Wouters et al. 2018, p. 9). Global governance is different from international governance in the sense that it could gradually reduce the dominance of states and their governments over rule-making and decision-making processes, strengthen the role of non-state actors and bring about more variation, democratization and multiplication in international decision-making processes and flexibility in international monitoring and implementation mechanisms (Bruhl and Rittberger 2001).

As global governance continues to be contested, and globalization seems to be facing a crisis, multiple classes of actors exist in the aspiring-to-beglobal system of governance - and the very existence of some actors has a strong impact on the way patterns of interconnectedness and interdependence are formed and sustained (Raudino and Poletti 2019, p.2). In this respect Raudino and Poletti distinguish between "globalization shapers," meaning actors that have the capacity to exert influence through large-scale mobilization of resources and are usually recognized as such by the other actors in the system, and "globalization takers," meaning those that adapt to international norms and standards set by others (Raudino and Poletti 2019 , p. 4). While the "globalization takers" do have agency, the "shapers" can hold increasing sway over them by simply carrying on their daily activities. This is certainly the case with China, which given its dimensions almost has no choice but to be a shaper of global norms. Regardless of the difficulties in defining either the BRI or global governance, if we approach China as a shaper we can see how the country and the initiative will have increasingly important roles in shaping global governance vis-à-vis globalization takers, which nevertheless remain crucial voices and challengers.

Much has been written already about the BRI and global governance due to China's importance as a trade and financial power, and the fact that the BRI is the Xi administration's major strategic international policy. A clear divide is often present in the literature between those apologizing for China and those who are a priori critical about the BRI and see a malevolent attempt to spread authoritarianism or other illiberal models of global governance. Moreover, the literature is often based on general and abstract theories that do not shed light on the real articulations of the BRI on the ground. For instance, Nadège Rolland provides an excellent overview in terms of international relations and geopolitics. It outlines some of the BRI's economic effects but does not explain in depth underlying economic mechanisms, such as its effects on the geography of international production networks, China's industrial overcapacities or the internationalization of the RMB (Rolland 2017a). Like Rolland, Kent Calder's work focuses 
convincingly on the geopolitical aspects of the BRI, but remains weaker on its economics and legal aspects (Calder 2019). The volume edited by Wei Liu, China's Belt and Road Initiatives: Economic Geography Reformation, Wang Yiwei's The Belt and Road Initiative: What Will China Offer the World in its Rise or Fei Xu's Belt and Road offer Chinese scholars and officials a perspective that is very close to China's official vision (Liu 2018; Wang 2016; Xu Fei 2018). Many of these works by Chinese scholars provide very few international sources or precise actual figures to back some of their claims, and rely more on official Chinese data and prospective analysis. Fanny M. Cheung and Ying-yi Hong's edited volume, Regional Connection under the Belt and Road Initiative: The Prospects for Economic and Financial Cooperation (2018), is written by contributors who almost exclusively have international relations backgrounds; its discussions remain far from the geoeconomic perspectives of the present book. Other books, such as The Belt and Road Initiative in the Global Arena: Chinese and European Perspectives by Yu Cheng, Lilei Song and Lihe Huang (2018), have a much more narrow focus than the present book. Ilan Alon and Wenxian Zhang's edited volume China's Belt and Road Initiative: Changing the Rules of Globalization (2018) has a very wide scope that includes peripheral case studies such as Swiss, New Zealander, Arctic and US connectivity - again very different from the present work. Bruno Maçães's work, The Dawn of Eurasia (2018), offers a long-term perspective on the integration of the Eurasian continent, but constitutes an essay rather than a rigorous scientific analysis of the BRI's effects.

This volume differs from those published so far because it provides alternative readings about the rationale behind the BRI as well as concrete cases from the ground that have not been discussed before. It deals with questions about connectivity and the financial and monetary implications of Chinese investments that have not yet been addressed. Most importantly, it includes new studies resulting from fieldwork that investigates the implementation of the BRI and its significance for global governance. Through its various contributions this volume demonstrates that the BRI is as complex and nuanced as global governance itself, and that its impact on global governance is far from linear. As the initiative has both positive and negative consequences, a more balanced approach is needed when considering its impact. Looking at the BRI and its effects on global governance on the ground, through concrete case studies, allows us to better understand and evaluate its governance and development outcomes.

The volume is divided into three parts. Part I, "Geoeconomics and Connectivity," provides a general introduction on the BRI's key geopolitical and economic aspects. In his chapter Christer Ljungwall introduces the concept of geoeconomic resilience and its basic factors, showing how these 
will ultimately allow the Chinese Communist Party to weld together and fully make use of its two main sources of legitimacy: economic wealth and nationalism. For Ljungwall, the solution to the dilemma of severe interstate crises is geoeconomic resilience, which would grant China the option of complying with nationalist demands to take aggressive action, while at the same time absorbing the consequences of such action and continuing to deliver on its promise of economic well-being. The fact that parts of the BRI seem designed to decouple China's economy from its dependence on the West and on maritime trade should be alarming to many. By increasing its geoeconomic resilience and possibly breaking free from this constraint as a result, China would be able to withstand and absorb the economic effects of sanctions or a naval blockade. This gives it the possibility of acting more assertively abroad, without having to worry about economic isolation badly damaging its economy and leading to political instability. The chapter examines the combination of potential economic and political factors related to the BRI that will lead to improved geoeconomic resilience, and that have helped China become more resilient to external shocks.

In his chapter Jean-Christophe Defraigne assesses to what extent the BRI can shift the balance of power within the world trading system by increasing connectivity across the Eurasian continent and its neighbourhood, transforming the current international production networks (IPNs) and creating a higher degree of economic interdependence between China and the countries targeted by BRI schemes. Defraigne contextualizes the amount of China's financial flows to the countries participating in the $\mathrm{BRI}$, and shows to what extent the BRI has generated a significant change in trade structures and IPNs that should strengthen Chinese economic influence in the Eurasian continent. His chapter examines whether Chinese FDI flows in the BRI region are likely to generate a geographical extension of production processes from Chinese firms across the Eurasian continent and transform the global division of labour in a manner that would significantly impact BRI recipient countries.

Another key concept in the BRI is connectivity. In his chapter ChengChwee Kuik offers a small-state perspective on the initiative in Southeast Asia, a prioritized region of China's economic statecraft, especially since Xi's announcement of the BRI in 2013. Viewing "connectivity" and "gaps" as symbiotic concepts, the chapter focuses on the bridging links and missed links in Beijing's BRI endeavours in the region. It contends that although China's BRI push - alongside several Southeast Asian states' pulls - is showing early signs of narrowing the physical and developmental gaps in several countries, the process has underscored and, ironically, widened perceptions and political gaps between China and host countries. Bridging 
links are being developed, but missed links persist. Persistent gaps and missed links across borders, essentially the products of power asymmetry, economic disparity and divergent domestic political imperative, have constrained and challenged China's BRI agenda. At the same time, the existing gaps may have motivated Beijing to devote more capital, diplomatic resources and political will to cross-border negotiation treadmills. The cycles of mutual adaptation and accommodation continue.

Another aspect of the BRI related to global governance is its fostering of collaboration with existing international institutions. In his chapter Suresh Nanwani explores the BRI's interface and collaboration with multilateral development banks (MDBs) - in particular the World Bank Group, the European Bank for Reconstruction and Development, the Asian Development Bank, the Asian Infrastructure Investment Bank, the New Development Bank and the European Investment Bank - as well as their impact on international cooperation and global governance. These six MDBs signed a historic joint memorandum of understanding with China on 14 May 2017 (China-MDBs MOU) to support the BRI. After discussing BRI cooperation and implementation with various sectors including MDBs, the author analyses the China-MDBs MOU and the MDBs' responses. Through the MOU, China is contributing to global governance, with the MDBs as support, by promoting connectivity networks and sustainable development. Nanwani also discusses the MDBs' projects, programmes and other activities in relation to the BRI in pursuit of their mandates on economic development, summarizing the varied approaches taken by these MDBs, and assesses whether other and complementary approaches could be taken to support the BRI. The chapter concludes on a positive note by discussing how China can increase the MDBs' support for the BRI and bolster the initiative further through international organizations like the United Nations Development Programme.

Part II of the volume, "Rationales of the BRI from China's Perspective," addresses some of the factors motivating China and the BRI. The initiative serves multiple purposes for China, both domestically and for its foreign policy. By creating new markets and balancing Chinese growth, the BRI could potentially improve the PRC's domestic economic security, helping to integrate China, especially its western regions, with the global economy according to its "going out" strategy. The initiative also has deeper geopolitical implications, in that the economic and strategic space that China is carving out along the new Silk Road will allow it to establish new alliances and increase its land power, thereby contributing to further balance the hegemony of the US, the current dominant sea power. The geopolitical and geoeconomic strategies behind the BRI rely on the large Asian infrastructure vacuum, which cannot be answered by the existing 
international development financing institutions (Shepard 2016). A recent ADB report shows how developing Asia requires investments of US\$26 trillion from 2016 to 2030 , or US\$1.7 trillion in infrastructure per year, if the region is to maintain its growth momentum, eradicate poverty and respond to climate change (Asian Development Bank 2010; Insill Park 2016, p. 66). This infrastructure, which includes transport, power, telecommunications, water supply and sanitation, is essential for the production of goods and services and for economic and social development. Investments in infrastructure in Asia could be justified by potentially profitable returns, as the area represents 55 per cent of the world's gross national product, 60 per cent of the population and 75 per cent of known energy reserves (Asian Development Bank 2010; Insill Park 2016, p. 66). China has used infrastructure investment heavily for its economic growth, to alleviate poverty and improve the standard of living of millions of people. ${ }^{7}$ As well as its use domestically as a fiscal stimulus to respond to the 2008-2009 global crisis, it has become the PRC's modus operandi abroad, in Africa, Latin America and Eurasia (Wilkins and Zurawski 2014).

Much scholarship has discussed the BRI as a strategy for China to get rid of overcapacity, but here Duncan Freeman challenges this view. By analysing the relationship between industrial overcapacity in China in the sectors of cement and steel and the BRI, his chapter assesses the low degree to which the BRI and the related policy of "production capacity sharing" has an impact in overcapacity in China, and how this domestic factor cannot fully explain the reasons for China's apparent reshaping of the global economic order through the BRI. For Freeman, overcapacity is a key domestic policy concern, but its reduction is not necessarily the primary goal of the BRI; even if it were the goal, he suggests, the initiative has had no significant impact on domestic overcapacity.

Another reason often cited as a key motivation for the BRI is the internationalization of the RMB. Jean-François Di Meglio's chapter shows the ambiguities of a currency's "internationalization" and argues that China has clearly gone backwards on the path of internationalizing the RMB in recent years. The reason for the protraction of this process is, he argues, the inward-looking structure of Chinese banking, financial and capital markets. For Di Meglio, the whole system, and even the whole BRI, finds its founding principle in the need to ensure a safe growth in the domestic economy for social stability. In spite of many attempts to "open up" and liberalize it, China's financial system continues to bounce back against domestic difficulties.

In his chapter Thierry Pairault looks at Africa and the role it has in the BRI. Various authors have seen the BRI in Africa as a way to secure resources that China depends upon but is not self-sufficient in, or infra- 
structure for resources (Alves 2013). The chapter raises the question of the place that the BRI could reserve for Africa and the 54 economies it comprises. It begins by focusing on Africa's economic importance for China in investment and trade, contextualized with the engagement of other international actors, and then examines the strategic part that Africa as a whole and African states are likely to play. In arguing that Africa serves as a springboard for China in its definition of a new global governance, Pairault demonstrates that Africa's importance in the BRI is currently more obvious from a geopolitical than from a strictly economic point of view.

Part III of the volume, "Cases from the Ground," brings together contributions that observe the actual impact of the BRI on the ground and how this can be revealing in terms of the initiative's broader implications for global governance. In her chapter Nargis Kassenova looks at the Kazakhstani government's active embrace of the opportunities brought by the BRI and shows how the country has adapted itself to the initiative as it rapidly unfolds. Astana has in fact aligned its national development plans with China's megaproject, and changed legislation and regulations in areas ranging from investment, finance and technical standards to land use and migration. These modifications are accompanied by efforts to improve its "doing business" ratings and adopt Organisation for Economic Co-operation and Development good governance standards to make the country attractive for investments from developed economies. The Kazakhstani government has to calibrate its approach by taking into account not only economic interests and capacities, but also national security concerns, external constraints and domestic public opinion. Kassenova's analysis of Kazakhstan's policies and choices, and the push and pull factors that shape them, contributes to our understanding of the impact of the BRI on global governance.

Uwe Wissenbach's chapter illustrates how Chinese financing and contractors have created a new development option for African governments seeking to deliver infrastructure mega-projects. It provides a study of the standard-gauge railway built by Kenya with Chinese assistance under the BRI between 2014 and 2017 - a project previously assessed as non-viable by the World Bank. The chapter emphasizes the Kenyan government's ability to set up a powerful centralized organizational structure to overcome governance challenges and coordinate work with the Chinese contractor to successfully deliver the railway. However, opacity and ballooning landacquisition costs suggest rent-seeking has inflated the cost to taxpayers, echoing several previous international corruption scandals in Kenya. At the level of the private sector, Kenyan agency was partly visible in vested interests opposing the project and partly in successful lobbying to access the closed procurement markets of the Chinese contractor. One of the 
most frequently raised issues regarding developing countries' engagement with the BRI is (over-)indebtedness, and in this case Kenya has developed a fiscal instrument to repay the Chinese loans. China's follow-up trade and investment in East Africa is believed to be a major element of the rationale for the rail project, although concrete measures to achieve this are still lacking and regional connectivity is limited. Data will have to be analysed over the next decade. The case suggests that a centralized approach in African government engagement with the BRI can deliver projects for a reasonable, albeit inflated, cost, while development benefits and socio-economic change require active management beyond the temporary governance model to organize project delivery.

Aaron Halegua's chapter explores the impact of the BRI on global labour standards primarily through a case study of a casino construction project in Saipan, part of the US Commonwealth of the Northern Mariana Islands. Imperial Pacific, a Hong Kong-based company, contracted multiple Chinese construction firms to build the casino, each of which considered the Saipan project a contribution to the BRI. Later on, widespread violations of US immigration and labour laws were detected, resulting in civil and criminal enforcement actions by federal authorities. The chapter uses the Saipan case as a starting point to examine Chinese overseas infrastructure and construction projects more broadly, including since the launch of the BRI. Despite policies and regulations instructing Chinese enterprises to safeguard labour rights and adapt to local rules, Chinese companies frequently implement the same labour practices employed at home, which often violate both Chinese and local laws. In terms of remedying the abuses, the firms operating in Saipan proved responsive to negative media reports generated by unpaid protesting workers. Such public displays of discontent and open news coverage may be impossible in BRI jurisdictions with different legal systems, however, or where Chinese investments are politically sensitive. Halegua argues that China can only achieve its financial interests and broader foreign policy objectives if its companies respect labour rights abroad, and considers several means of encouraging increased compliance with Chinese and local labour standards. He concludes with some policy advice on how to improve labour standards abroad.

In his concluding reflections, "China's Belt and Road Initiative imagination and reality," François Godement provides critical perspectives on the BRI. While recognizing its multifaceted dimensions and its amorphous nature, he discusses the initiative as a strategy, albeit a hybrid one, that lacks a grand design and in which the central Chinese state often lacks control over its economic actors abroad. After describing a possible clash of norms defining future global governance between China's BRI on the 
one hand and Europe and other liberal countries on the other, Godement provides some policy recommendations on how to engage with the initiative in order to commonly shape the future structures of global governance.

The contributions to this volume show that the BRI has not been designed specifically to challenge the existing institutional global governance framework. Rather than being a comprehensive global strategy to reshape governance, it has multiple and changing goals. It has been conceived in part to foster the development of China's western provinces by creating commercial corridors to Central and South Asia. Early on, some perceived the BRI as also being a means to solve industrial overcapacity problems, but we now know that this issue could be better tackled by domestic policies than by BRI-related projects. The BRI can be considered an attempt to secure access to markets and strategic raw materials. It seeks to counter the effects of post-2008 protectionism and of US diplomatic offensives, such as the "pivot to Asia," the TPP and the TTIP. Finally, the BRI constitutes a tool of industrial policy to ease the internationalization of Chinese businesses, and to a certain extent to promote the diffusion of some Chinese technological standards.

China's economic size has generated fears, notably in the US, the EU and Japan, that the BRI could challenge the functioning of global governance and generate destabilizing effects, including: (i) weakened international financial institutions - such as the IMF and the World Bank - as some BRI recipient countries governments find alternative ways to finance infrastructure projects; (ii) a weakened multilateral trading system as BRI recipient countries experience trade diversion effects and trade dependence on China; (iii) debt traps and increasing Chinese leverage on local governments due to the financial unsustainability of some BRI-related projects; and (iv) weakened multilateral and bilateral schemes to contain corruption and pollution, impose higher environmental standards and improve local good governance practices.

The case studies and data outlined in this volume put the BRI in perspective, however, and reveal that its impact has often been overestimated. Its funding level is not exceptional by world standards; it is comparable to existing programmes initiated by large economies, notably the EU. The BRI has not significantly altered the existing international production networks or the international division of labour, generating minimal trade diversion effects. It has not yet been used as a major tool to internationalize the use of the RMB at the expense of the US dollar or other important currencies.

China's authorities do not present the BRI as exclusively Chinese but as multilateral. They have promoted cooperation with important Western economies and adopted standard international prudential rules for one of the major institutions involved in the BRI, the AIIB. China is using the 
BRI to generate increased economic interdependence with the Eurasian economies to avoid being isolated, notably by the US containment strategy.

By improving connectivity and creating corridors, the BRI should help integrate the Eurasian continent and its neighbourhood. This should reduce transport costs, foster trade, widen consumer choice, enable a more efficient international division of labour, and better insert some landlocked and isolated countries in the global economy.

The arguments above explain why the BRI should not be perceived as a comprehensive, assertive strategy to reshape global governance. The new Silk Road does generate governance problems, however, and it does not present an alternative to a weakening of multilateralism, notably in trade, finance, labour standards and the environment. The Chinese authorities, like other major economic powers, are using bilateral aid schemes to promote their projects outside the scrutiny of multilateral institutions such as the World Bank, the IMF and even the AIIB. Like similar projects launched by other large economies, BRI-related infrastructure schemes could generate "white elephants," debt problems and environmental damage, and do not improve labour or environment standards. As the Chinese government does not currently have the capacity to monitor the thousands of economic and political actors involved in the various BRI-related projects across dozens of countries, it cannot be expected to fundamentally improve global governance, even should it wish to. Despite these flaws, the BRI could generate some long-term positive effects as it increases the level of investment in peripheral economies that have been left behind, particularly in Central Asia, South Asia, the Middle East and the Balkans. It should also facilitate transport across the Eurasian continent.

Overall, while the BRI should not be seen as a threat to global governance, it does not provide solutions to the serious global challenges we are faced with in terms of the environment, financial stability, trade conflicts, labour standards, migration and peace. The BRI will not be sufficient to lift underdeveloped economies out of poverty; nor will it upgrade labour and environment standards, or prevent future trade wars and global financial crises. Such challenges to global governance will require solutions designed by all stakeholders. This world will not be saved by either a Washington Consensus or a Beijing Consensus, but only by renewed multilateral cooperation across all policy fields.

\section{NOTES}

1. In particular, the PRC is interested in developing six economic corridors: 1) PRC, Mongolia and Russian Federation; 2) New Asia, European Continental Bridge; 3) PRC, 
Central Asia and West Asia; 4) PRC and Mainland Southeast Asia; 5) PRC and Pakistan; 6) PRC, India, Myanmar and Bangladesh. See NDRC (2015), Grieger (2016), Aris (2016).

2. In 2015, China had one of the largest merchandise trade surpluses in history, at over US\$450 billion. See Miner (2016, p. 13).

3. In particular articles 51-54 of the 13th Five-Year Plan. See State Council of the People's Republic of China (2016).

4. The term was coined by US economist C. Fred Bergsten in 1996.

5. The EU Commission adopted a strategy named "Global Europe: competing in the world" in 2006.

6. These agreements often include TRIPs, TRIMs, trade facilitation and procurements provision, and can even set up Investor-State Dispute Settlement mechanisms.

7. Poverty and infrastructure development have a complex relationship. It is not necessarily true that poverty is reduced if infrastructure is built, as some may still lack access to such infrastructures. For example, building a highway is less likely to benefit people who cannot afford cars. See Pouliquen (2000).

\section{REFERENCES}

Alon, I. and W. Zhang (eds) (2018), China's Belt and Road Initiative: Changing the Rules of Globalization, Cham: Palgrave Macmillan.

Alves, A. C. (2013), 'China's "win-win" cooperation: Unpacking the impact of infrastructure-for-resources deals in Africa', South African Journal of International Affairs, 20 (2), 207-26.

Aris, S. (ed.) (2016), 'One Belt, One Road: China's vision of "connectivity”, CSS Analyses in Security Policy ETS Zurich, September, No. 195.

Asian Development Bank (2010), 'Central Asia atlas of natural resources', accessed 24 June 2017 at https://www.adb.org/sites/default/files/publication/27508/centralasia-atlas.pdf.

Baum,R.(2001), 'From "strategic partners"to "strategiccompetitors": George W. Bush and the politics of U.S. China policy', Journal of East Asian Studies, 1, 191-220.

Bhagwati, J. (2004), 'Don't cry for Cancun', Foreign Affairs, 1 January.

Bruhl, T. and V. Rittberger (2001), 'From international to global governance: Actors, collective decision-making, and the United Nations in the world of the twenty-first century', in V. Rittberger (ed.), Global Governance and the United Nations System, New York: United Nations University Press.

Cai, P. (2017), 'Understanding China's Belt and Road Initiative', Lowy Institute for International Policy, 22 March, retrieved from https://www.lowyinstitute.org/ publications/understanding-belt-and-road- initiative.

Calder, K. (2019), Super Continent: The Logic of Eurasian Integration, Stanford: Stanford University Press.

Callahan, W. A. (2016), 'China's "Asia Dream": The Belt and Road Initiative and the new regional order', Asian Journal of Comparative Politics, 1 (3), 226-43.

Cheng, Y., L. Song and L. Huang (2018), The Belt and Road Initiative in the Global Arena: Chinese and European, Singapore: Springer.

Cheung, F. and Y.-Y. Hong (eds) (2018), Regional Connection under the Belt and Road Initiative: The Prospects for Economic and Financial Cooperation, London: Routledge.

Chin, H. and W. He (2016), 'The Belt and Road Initiative: 65 countries and beyond', Global Sourcing and Fung Business Intelligence Centre (May), accessed 23 
July 2017 at https://www.fbicgroup.com/sites/default/files/B\%26R_Initiative_65_ Countries_and_Beyond.pdf.

Clinton, H. (2011), 'America's Pacific century', Foreign Policy, 11 October.

Defraigne, J.-C. and P. Nouveau (2017), Introduction à l'économie européenne, Louvain-la-Neuve: De Boeck.

De Gucht, K. (2014), 'The Transatlantic Trade and Investment Partnership: Where do we stand on the hottest topics in the current debate?' European Commission, accessed 17 July 2019 at http://europa.eu/rapid/press-releaseSPEECH-14-52en. htm.

European Commission and High Representative of the European Union for Foreign Affairs and Security Policy (ECHR 2019), Joint Communication to the European Parliament, the European Council and the Council: EU-China-A Strategic Outlook, Brussels, 12 March, https://ec.europa.eu/commission/sites/ beta-political/files/communication-eu-china-a-strategic-outlook.pdf.

Grieger, G. (2016), 'One Belt One Road (OBOR): China's regional integration initiative', July, European Parliamentary Research Service Briefing Paper PE 586.608, accessed 23 June 2017 at http://www.europarl.europa.eu/RegData/etudes/BRIE/ 2016/586608/EPRS_BRI(2016)586608_EN.pdf.

Griffiths, R. (2017), Revitalising the Silk Road: China's Belt and Road Initiative, Leiden: HIPE.

Horn, H., P. Mavroidis and A. Sapir (2009), Beyond the WTO? An Anatomy of EU and US Preferential Trade Agreements, Brussels: Bruegel.

Insill Park (2016), 'US-China competition in Asia-Pacific Region: The AIIB and the New Global Order?' CUNY academic works, accessed 24 June 2017 at http:// academicworks.cuny.edu/cc_etds_theses $/ 595$.

Liu, W. (ed.) (2018), China's Belt and Road Initiatives: Economic Geography Reformation, Singapore: Springer.

Maçães, B. (2018), The Dawn of Eurasia, New York: Allen Lane.

Miner, S. (2016), 'Economic and political implications', in S. Djankov and S. Miller (eds), China's Belt and Road Initiative: Motives, Scope, and Challenges, Washington DC: Peterson Institute for International Economics.

National Development and Reform Commission, Ministry of Foreign Affairs, and Ministry of Commerce of the People's Republic of China (NDRC 2015), 'Vision and actions on jointly building Silk Road Economic Belt and 21st-Century Maritime Silk Road', accessed 23 June 2017 at http://en.ndrc.gov.cn/newsrelease/ 201503/t20150330_669367.html.

Naughton, B. (2010), 'China's distinctive system: Can it be a model for others?' Journal of Contemporary China, 19 (65), 437-60.

Navarro, P. (2015), Crouching Tiger: What China's Militarism Means for the World, New York: Prometheus.

Pillsbury, M. (2015), The Hundred-Year Marathon: China's Secret Strategy to Replace America as the Global Superpower, New York: Henry Holt.

Pouliquen, L. (2000), 'Infrastructure and poverty', World Bank Report, December, accessed 24 June 2017 at http://siteresources.worldbank.org/INTPOVERTY/ Resources/WDR/Background/pouliquen.pdf.

Raudino, S. and A. Poletti (2019), 'Introduction', in S. Raudino and A. Poletti (eds), Global Economic Governance and Human Development, Abingdon and New York: Routledge.

Rolland, N. (2017a), 'China's Eurasian century? Political and strategic implications of the Belt and Road Initiative', National Bureau of Asian Research. 
Rolland, N. (2017b), China's Eurasian Century, Cambridge: Cambridge University Press.

Roychoudhury, A. (2017), 'K V Kamath points to NPA time bomb, says India is running out of time', Business Standard, 31 March, accessed 23 June 2017 at http://www.business-standard.com/article/finance/k-v-kamath-points-to-npatime-bomb-says-india-is-running-out-of-time-117033001422_1.html.

Shambaugh, D. (2013), China Goes Global, Oxford: Oxford University Press.

Shepard, W. (2016), 'The New Silk Road is not Chinese, it's international', Forbes, 14 October, accessed 12 August 2017 at https://www.forbes.com/sites/wadeshep $\operatorname{ard} / 2016 / 10 / 14 /$ regardless-of-what-beijing-says-the-new-silk-road-is-not-chinese /\#3dd60da55ec2.

State Council of the People's Republic of China (2016), '13th Five-Year Plan on National Economic and Social Development', accessed 23 June 2017 at http:// www.gov.cn/xinwen/2016-03/17/content_5054992.htm.

Wang, Y. (2016), 'Offensive for defensive: The Belt and Road Initiative and China's new grand strategy', Pacific Review, 29 (3), 455-63.

Wang Yiwei (2016), The Belt and Road Initiative: What Will China Offer the World in its Rise, Beijing: New World Press.

Wilkins, K. and A. Zurawski (2014), 'Infrastructure investment in China', Bulletin of Reserve Bank of Australia, accessed 24 June 2017 at https://www.rba.gov.au/ publications/bulletin/2014/jun/pdf/bu-0614-4.pdf.

Woodward, J. (2017), The US vs. China, Manchester: Manchester University Press.

Wouters, J., J.-C. Defraigne, P. Defraigne and T. de Wilde (2012), China, the European Union and Global Governance, Cheltenham UK and Northampton, MA, USA: Edward Elgar Publishing.

Wouters, J., C. Ryngaert, T. Ruys and G. De Baere (2018), International Law: A European Perspective, Oxford: Hart.

Xi, J. (2013), 'Promote friendship between our people and work together to build a bright future', Ministry of Foreign Affairs of the People's Republic of China, accessed 23 June 2017 at http://www.fmprc.gov.cn/mfa_eng/wjdt_665385/ zyjh_665391/t1078088.shtml.

$\mathrm{Xu}$ Fei (2018), The Belt and Road, Berlin: Springer.

Zhao, Suisheng (2010), 'The China Model: Can it replace the Western model of modernization?' Journal of Contemporary China, 19 (65), 419-36.

Zhou, Weifeng and M. Esteban (2018), 'Beyond balancing: China's approach towards the Belt and Road Initiative', Journal of Contemporary China, 27 (112), 487-501. 